\title{
Effect of PBL Learning Model on Critical Thinking Skills Students Learning Course Design of Geography
}

\author{
Yuli Ifana Sari \\ Department of Geography Education \\ Kanjuruhan Malang University \\ Malang, Indonesia \\ Corresponding email: ifana@unikama.ac.id \\ Mustika Arif Jayanti \\ Department of Geography Education \\ Kanjuruhan Malang University \\ Malang, Indonesia \\ Achmad Maulana Malik Jamil \\ Department of Geography Education \\ Kanjuruhan Malang University \\ Malang, Indonesia
}

\begin{abstract}
Problem Based Learning (PBL) model used to teach students to think critically. The main advantages of this model lies in the phases directing students on actual issues that can improve critical thinking skills. The purpose of this study is to test the influence of the $P B L$ learning model on students' critical thinking skills. This study is a quasi-experimental research using nonequivalent control group design. The research subject is determined based on the similarity of the average value of midterms students and measurement instruments using essay test. The results of measurements of critical thinking in the form of data and analyzed using t-test using SPSS 16.0 for Windows. Based on the data analysis, average gain score critical thinking skills in the classroom experiment that is equal to 32.3 , while the control class at 14.2. The results of t-test analysis independent sample t-test shows that the PBL learning model ph-level gained 0.00 less than 0.05 . This means that $\mathrm{H}_{0}$ refused and $\mathrm{H}_{1}$ accepted so there is the influence of PBL learning model on critical thinking skills.
\end{abstract}

\section{Keywords_Problem Based Learning Model, critical Thinking}

\section{INTRODUCTION}

Critical thinking skills can not grow by itself as the physical development of man. This capability should be trained through a stimulus that requires a person to think critically. One way to organize learning that helps students develop critical thinking skills to face the real problems that developed in the environment. Nafiah (2014) state that "by $P B L$ student get experience in handle realistic problems, and pressure in use communication, cooperation, and sources to formulated idea and develop thinking skill". To build skill in critical thinking lecture can give learning experience with learning design. Lecture design learning with give problem that involved critical thinking student and analytical process based on the real problem.

$P B L$ is learning an innovative model that is developed based on constructivism paradigm. The essence of that learning model is reoriented learning from the first focus on the lecture and now become focus on the student. Besides that, Yoswita, et al. (2012) state "learning model based on problem give an opportunity use potential student thinking in activities to solve the problem and take a decision in real life context". The Boud \& Felleti, (1998) state that "PBL is constructive way in learning use problem as stimulus and focus on student activity. That model is suitable with innovation education concept in technical, especially for: student get basic science that useful for solve the problem, the student actives and be autonomous with showing material integration and relevant with the reality and student able to think critically and develop their initiative".

The research that has been done by Tosun \& Taskesenligil, (in Hartati \& Sholihin, 2015) show that "PBL has positive contribution for critical thinking skill that is part of cognitive sub-dimension and metacognitive self-regulation and managerial strategy capacity resources". The implementation of $P B L$ learning model is done regularly from formulating problem, give argument, do deduction, induction, evaluation, consider and done. According to PBL (1980) this learning model has benefits that are "PBL model is based on assumption that creativity is process and study result; (2) it is done to all student in various background and knowledge level; (3) it integrate cognitive dimension and affective in development; (4) it involved in phase critical skill convergent 
and divergent in solving problem; and (5) it has in phase development systematically with various methods and technique for each phase that is applied flexibility".

PBL opinion state that this model has flexible characteristic according characteristic needed. That model also develops critical skill divergent and convergent. Guilford, (in Sari \& Putra, 2015) state that "divergent thinking has wide characteristic that identified by fluently, flexible, and modern. While convergent thinking has critical characteristic and analytical discover one right answer". So, it can be said that $P B L$ model can be used to develop critical thinking skill and creative all at once.

From various theory above can be concluded that with given real problem, student is motivated and trained to think how way solve the problem with multi-solution. Solving with multi-solution can develop creative thinking skill. In other that, student also motivated to find appropriate solution from various solutions that has been said with judgments by understanding and student experience. These are train and develop critical thinking skill. One of learning model that can influence to critical thinking student is Problem Based Learning.

One of thinking form is think high level that materialized in critical and creative thinking. Develop high thinking on the student is one important thing because problem level in all aspect of modern life is complicated. Sari (2013) gives the reason why critical thinking is important for student that is "(1) critical thinking can make satisfaction and happiness, (2) critical thinking help student become more success in solving problem. This is because critical thinking as skill for see various possibility in solving problem, (3) critical thinking create possibilities to solve problems in the future, and (4) critical thinking can appear the big effect in life that possible improve the quality human life".

The effort to develop critical thinking and creative with education substantively has been done in presences of constructivism paradigm. According Sari (2013) in mentioned paradigm is hoped that "student more active and creative reconstruct learning experience. Student not only as receiver of information from lecture, but active in reconstruct of knowledge". Lecture as facilitator that learn so student become active physically and psychology with thinking in order to learning became have sense. As main component in learning lecture should aware and make serious effort in solving problem that occurs.

Development student potential becomes human who has critical thinking and creative must be focused in learning. That critical thinking and creative can be developed by lecture with train student in habituate of each learning activity. In constructivist learning knowledge will be built by students active through the development of the mental process. Constructivism also contains a teaching that emphasizes the process, which means that the model PBL motivate students to construct their own knowledge through investigation with the aim to solve problems and improve critical thinking skills contained in PBL syntax.
The steps on $P B L$ learning is purposed for teach thinking high level. This is including critical thinking and creative. Collateral with the advantages of $P B L$ model in developing critical thinking skill and creative, empiric finding by Ayuningrum \& Susilowati, (2005) give evidence that "there are significant differentiate between critical thinking student that get PBL learning model with critical student in usual learning". This research also shown that student with lower school quality also has improvement significantly in creative thinking skill and more able to solve the problem, this indicate that $P B L$ learning model indeed superior in develop thinking with include cognitive and affective process by discussion process in solving problem.

\section{METHOD}

This research is quasi experiment. Research planning is non-equivalent control group design. Research plan is use two class groups that are considered as research subject, that is experiment class and control class. Experiment group is given PBL learning model while control group isn't given that or they give speech class, discussion, and answer question. The cord variable in this research is critical thinking. The free variable is $P B L$ learning model.

Subject research is considered based on similar average midterm test student score. Consideration of class instrument test with class review has get Learning Course Design of Geography learning. The instrument use is essay test. Test is given to know the changing of critical thinking student skill. This test is given in early learning (pre-test) for experiment class and control class. Pre-test is done to get critical thinking skill score early student in Learning Course Design of Geography subject. After that, student is given post-test. Before using essay question is tested first in other class for knowing the difficulties level, differentiate power, validity, and reliability matter.

The data collecting technique which is used in this research those are: 1) the instrument for collect data in this research is kill test on critical thinking; 2) pre-test is test which is done before teaching learning process with a certain attitude given. This test is given for knowing critical thinking student before give attitude. 3) Post-test is test which is given after learning finished; the purpose is for knowing critical thinking student after give attitude not only for experiment class but also in control class.

The data analysis which is used to process data of this research uses statistic method. Statistic that is used is descriptive and inferential statistics parametric analysis. Descriptive statistics analysis is used to describe or give data explanation in form table, graphic, and histogram from average score in order to get easily about image of object characteristic from that data. While parametric inferential statistics analysis is used to hypothesis test. Hypothesis test in this research is use t-test. Significant level that is used that is 5\% use SPSS 16.0 for Windows program. 


\section{FINDING AND DISCUSSION}

TABLE I. SCORE AVERAGES CRITICAL THINKING SKILL PRE TEST AND POST-TEST LEARNING COURSE DESIGN OF GEOGRAPHY SUBJECT

\begin{tabular}{|c|l|c|c|c|c|}
\hline Class & $\begin{array}{l}\text { Learning } \\
\text { Variable }\end{array}$ & $\begin{array}{c}\text { Pre } \\
\text { Test }\end{array}$ & Category & $\begin{array}{c}\text { Post } \\
\text { Test }\end{array}$ & Category \\
\hline Experiment & $P B L$ & 43.2 & Fair & 83.2 & Good \\
\hline Control & $\begin{array}{l}\text { Speech, } \\
\text { discussion, } \\
\text { answer } \\
\text { question }\end{array}$ & 39.7 & Fair & 62.9 & Good \\
\hline
\end{tabular}

The average score critical thinking pre-test for experiment class and control class is fair. For post-test experiment class and control class is in good category, but experiment class has average higher than control class that are for experiment class is 83.2 and control class is 62.9. Based on the accounting is obtained gain score average critical thinking skill in experiment class is 40 while in control class is 23.2 . The result of analysis $t$-independent sample t-test for critical thinking skill show that $P B L$ learning model is obtained p-level 0.00 smaller than 0.05 . It means that $\mathrm{H}_{0}$ is reject and $\mathrm{H}_{1}$ is receive so there is influence $P B L$ learning model for critical thinking skill and creative.

The analysis result show that there is differentiate of critical thinking skill level of experiment class and control class on Learning Course Design of Geography. The differentiate of test score on critical thinking process between experiment class and control class occurs because produce teaching learning more live or fresh in experiment class. This is supported with $100 \%$ student said that study condition use PBL model more interesting and enjoying. The student opinion with PBL model is the situation is not quite but become more noise and violent because there is debate about the way to solve finishing learning sets of equipment that consist of academic calendar, effective school week, syllabus, yearly program, semester program, KKM scoring, and lesson plan (RPP) not only KTSP curriculum but also curriculum 13. This means that $P B L$ learning influence to improvement critical thinking skill of student.

$P B L$ model characteristic is give real problem in one of step of learning, such as Wulandari (2011) said that " $P B L$ is designed with confrontational learning by contextual problem which related with learning material so the student know why they study then identify problem and collect information from study resources, then they discuss together with their friends in their group to get solution and reach the purpose of the learning".

That model can optimize all potential of student active, not only physical but also psychological. $P B L$ learning can train student active and thinking critically, besides that, there is cooperation in groups to reach learning purpose equally and student get experience their self to solve problem or assignment in form of learning set of equipment.

By solving problem student will find facts previously then make hypothesis and explain to take conclusion. After that student choose the best solution and make in detailed in operational idea. Connected activities indirectly bring student to thinking high level and aim to critical thinking. This is like states by Liliasari, (2000) that "learning that can improve critical thinking is learning when student active and do the assignments". Learning Course Design of Geography is subject that supplies the student as teacher candidate in making learning set equipment. Because of that, $P B L$ is suitable for used in student learning in order to they try to make set of equipment first after that they present and lecture as facilitator in study.

Steps or syntax $P B L$ is able to improve critical thinking. Those steps such as: formulate problem, give argument, do deduction, induction, evaluation, consider, and done. $P B L$ give authorship to student for study according to their interest and attention, so in $P B L$ student will involved intensive and active, that finally able to make student continue in study and can improve critical thinking. Given real problem will stimulate curiosity, want to observed, and want to involve in one bigger problem. Curiosity of problem will stimulate student want study and understand concept as material to find some solution until conclusion of that solution which appropriate in solving problem.

\section{CONCLUSIONS AND SUGGESTIONS}

\section{A. Conclusion}

$P B L$ learning model influences significantly to critical thinking skill student of the Learning Course Design of Geography.

\section{B. Suggestions}

- For lecture, in applying PBL learning model is recommended for allocate more time of each learn especially to formula the problem.

- For the next researcher, is recommended to test the influence of PBL learning model in other variable.

\section{ACKNOWLEDGMENTS}

This activity can be carried out thanks to the support of the student of Geography Education 2013 University of Malang Kanjuruhan thus implementing a series of independent research LPPM DIPA can run well.

\section{REFERENCES}

[1] Ayuningrum, Diah \& Susilowati, Sri Mulyani Endang, 2015. Pengaruh Model Problem Based Learning Terhadap Keterampilan Berpikir Kritis Siswa SMA Pada Materi Protista. Journal of Biology Education. Vol 4 (2): 124-133.

[2] Boud, D., Feletti, The Challenge of Problem Based Learning. Routledge: London, 1998.

[3] Hartati, Risa \& Sholihin, Hayat. 2015. Prosiding Simposium Nasional Inovasi dan Pembelajaran Sains 2015 (SNIPS 2015) 8 dan 9 Juni 2015, Bandung, Indonesia Meningkatkan Kemampuan Berpikir Kritis Siswa Melalui Implementasi Model Problem Based Learning (PBL) Pada Pembelajaran IPA Terpadu Siswa SMP. [web log post]. Retrieved from www.portal.fi.itb.ac.id

[4] Liliasari. 2000. Model pembelajaran IPA untuk meningkatkan keterampilan Berpikir Tingkat Tinggi Calon Guru Sebagai 
Kecendrungan Baru Pada Era Globalisasi. Jurnal Pengajaran MIPA, 2 (1): 55-66.

[5] Nafiah, Yunin Nurun. 2014. Penerapan Model Problem- Based Learning Untuk Meningkatkan Keterampilan Berpikir Kritis dan Hasil Belajar Siswa. Jurnal Pendidikan Vokasi, Vol 4 (1): 125-143.

[6] PBL, D.J. 1980. A Preliminary Models of Creative Learning. Gifted child Quarterly, 24f, 127-138.

[7] Sari, Yuli Ifana. 2013. Penerapan Model Pembelajaran PBL Pada Matakuliah Geografi Ekonomi untuk Meningkatkan Kemampuan Berpikir Kritis Mahasiswa Kelas A Universitas Kanjuruhan Malang. Jurnal Pascasarjana. [web log post]. Retrieved from http://library.um.ac.id/ptk/index.php?mod=detail\&id=61446.

[8] Sari, Yuli Ifana \& Putra, Dwi Fauzia. 2015. Pengaruh Model Pembelajaran Treffinger terhadap Kemampuan Berpikir Kritis dan Kreatif Mahasiswa Universitas Kanjuruhan Malang. Jurnal Pendidikan Geografi. Vol 2 (20): 30-38.

[9] Wulandari, Nadiah Sjarkawi \& Damris, M. 2011. Pengaruh Problem Based Learning dan Kemampuan Berpikir Kritis Terhadap Hasil Belajar Mahasiswa. Jurnal Tekno-Pedagogik, Vol 1 (1): 14-24.

[10] Yoswita, Fertika Dwi \& Pramudiyanti \& Marpaung \& Rini, Rita T. 2012. Pengaruh Model Pembelajaran Problem Based Learning (PBL) Terhadap Kemampuan Berpikir Kritis Siswa. Jurnal Biologi, [web log post]. Retrieved from www.eprints.uny.ac.id, 